\title{
Economic valuation of grassland utilization improvement in the Western Balkans
}

\author{
Željko Vaško ${ }^{*}$ and Gordana Rokvić1 \\ ${ }^{1}$ University of Banja Luka, Faculty of Agriculture, 78000 Banja Luka, Bulevar Petra Bojovića 1a, \\ Bosnia and Herzegovina
}

\begin{abstract}
Grassland is land permanently overgrown with grasses that can be used for grazing or preparing fodder. When identifying and delineating grassland areas from other agricultural areas, criteria can be their purpose (land cover) or their use (land use). The processes of depopulation and deagrarization of rural areas increase the surfaces of unutilized grasslands and decrease of their use for agricultural purpose. The purpose of research presented in this paper is the analysis of transformation of grassland area in six Western Balkans countries/territories from covered to used status. During the research, the methods of quantitative modelling and simulation were combined. Starting from existing grassland areas (which are equalized with permanent meadows and pastures), the intensity of their use was determined by calculating the grazing livestock density (GLD) index. Generally, grasslands are used extensively for feeding ruminants in the WB region, and great part of the area is not used at all, so the average GLD index is 0.88 with significant variations between countries. Three countries (Bosnia and Herzegovina, Montenegro and North Macedonia) have a GLD of 0.5 or less and there is space for them to increasing the number of ruminants up to 1.1 million livestock standard units (LSU) and increasing livestock density up to one LSU per ha of grassland. The conclusion is that, depending on the scenario, i.e. the structure of ruminant stock (cattle, sheep and goats), the value of livestock production in the Western Balkans could increase from 498 to 655 million EUR, still without environmental pressure of grazing on grassland area.
\end{abstract}

Keywords: grasslands, ruminants, grazing livestock density, Bosnia and Herzegovina.

JEL Classification: $Q 15 ; Q 510$

\section{Introduction}

Grasslands play a multiple role in economic development and derive multiple benefits, with one of the primary benefits being a source of animal nutrition [1]. Grasslands also play an important role in greenhouse gas mitigation, particularly in terms of global carbon storage and further carbon sequestration [2]. Thus, grasslands are essential for both, food supply and environment protection. If grasslands are used in a sustainable way, so as to enable the

*Corresponding author: zeljko.vasko@,agro.unibl.org 
conservation of biological diversity, their use is declared as High Natural Value farming. Grasslands is the primary source of forage for ruminants, by grazing or production of hay, silage or other fodder. Conserved and grazed grasses are complete feeds, rich in energy, proteins and minerals [3]. Also, the use of grassland biomass for energy production has become competition to grazing, although energy low-productive biomass usually does not economically justify such use.

In general, the Western Balkan countries suffer from the lack or unreliability of the data on the number of livestock, and the structure of the use of agricultural land. National systems for collecting and monitoring this data have a number of shortcomings and limitations. The usual databases from which these survey data are extracted, such as FAOSTAT or EUROSTAT, take over data from national statistical institutions, so that deficiencies are transferred from the national level to these databases. In most Europe countries, grasslands are affected by two opposite trends: intensification of their use or abandonment [4]. While grassland area have been heavily reduced during the 20th century all over Europe [5], in the Western Balkans those areas are increasing, mostly due to depopulation and deagrarization of rural areas $[6,7]$, but are not utilized to a significant extent. The decline in grassland grazing was also influenced by the extinction of nomadic practices (special characteristic of sheep breeding).

Grassland areas are usually designated as ANC (areas with natural constraints) due to certain natural limitations for agricultural production, that have enabled these areas for financial compensation provided within CAP budget.

In terms of the traditional or intensive use of grasslands, the interests of different groups intertwined, which are sometimes conflicting and sometimes close. These are mostly the interests of environmentalists $[8,9,10,11]$, farmers $[12,13]$, spatial planers $[14,15,16$, 17], tourismologists $[18,19]$. These interests are ranging from single to multifunctional role of grasslands. Natural and semi-natural grasslands (or High Nature Valued grasslands) with semi-intensive use, provide benefits for both, livestock husbandry and biodiversity conservation, supporting not only productivity but also biodiversity.

\section{Material and Method}

As noted by Van den Pol-van Dasselaar et al. [20], Europe is experiencing less grazing, and the same applies to the Western Balkans, where farming and feeding systems continue to rely on natural grasslands. The primary goal of the research was to determine the state of grassland utilization (also known as perennial meadows and pastures) in relation to the number of ruminants (cattle, sheep, and goats) depending on available grasslands. The research plan consists of six phases (Figure 1).

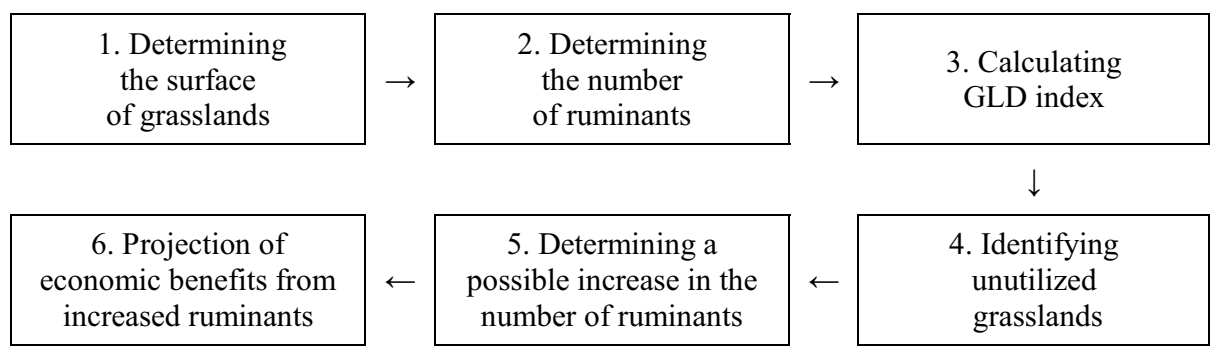

Figure 1. Research path

The next goal of the research was to determine the possibilities and effects of greater use of available grassland for livestock breeding, by applying the methods of calculation and modelling. The starting point is that excess of grasslands can be efficiently used to feed 
more ruminants and increase the production of meat and other products, following the standard of 1 standard livestock unit (SLU) per 1 ha of grassland. The principle of 1 ha of grassland being sufficient to provide daily food intake for one livestock unit, has been found in other studies on grazing forage self-sufficiency [21, 22, 23, 24].

The survey covers the countries/territories of the Western Balkans that are currently outside the EU: Albania (AL), Northern Macedonia (MK), Kosovo* (XK), Montenegro (ME), Serbia (RS) and Bosnia and Herzegovina (BA).

The research was primarily based on desk research method of collecting and processing data from secondary sources. The source of data on agricultural land and number of livestock was FAOSTAT for all countries [25], except for Kosovo for which the Kosovo Agency of Statistics [26] was consulted. All data on grasslands and livestock refer to 2018.

The grazing livestock density (GLD) index is calculated as the stock of grazing animals (cattle, sheep, goats) expressed in livestock standard units (LSU) per hectare of grassland. The EUROSTAT coefficients were used to convert the number of heads into the number of livestock units.

The increase in the number of ruminants was modelled on the basis of currently unutilized grassland area with the initial assumption $G L D=1$ in two scenarios. The first scenario (S1) is an increase in the number of ruminants based on the current ratio between cattle $\left(X_{1}\right)$, sheep $\left(X_{2}\right)$ and goats $\left(X_{3}\right)$ in particular country, and the second scenario (S2) is based on a structure in which cattle make up $55 \%(\mathrm{a}=0.55)$, sheep $40 \%(\mathrm{~b}=0.40)$ and goats $5 \%(\mathrm{c}=0.05)$ of the total number of ruminants.

$$
\begin{gathered}
\text { (S1): } \mathrm{Y}_{1}=\mathrm{a} X_{1}+\mathrm{b} X_{2}+\mathrm{c} X_{3} \\
(\mathrm{~S} 2): \mathrm{Y}_{2}=0.55 X_{1}+0.40 X_{2}+0.05 X_{3}
\end{gathered}
$$

\section{Results}

\subsection{Definition and delineation of grasslands}

Grasslands are the largest ecosystems in the world, further defining that "grassland " may be ground covered by vegetation dominated by grasses, with little or no tree cover [27]. Similarly, Velthof et al. [28] stated that grasslands cover more than a third of the European agricultural area, and draws attention to two dominant focuses in grassland definition, land cover or land use. Sanderson et al. [27] identified grasslands as a land dominated by grasses that animals can graze or can be used for mowing to prepare hay. As Lesschen et al. [29] mentioned so far there exists no general overview and typology of grasslands in Europe. They indicated differences in grassland typologies and differences in grassland areas depending on the data source (FSS, FADN, ECS, LPIS, LUCAS, EW-MFA, FAOSAT, UNFCCC, OECD, etc.). The problem of identifying grassland areas present in EU is even more pronounced in the Western Balkans (WB), which during their transition faced the collapse of the previous fairly well-regulated agricultural land monitoring system and insufficient capacity in establishing new systems in place (some WB countries do not even know the exact surface of agricultural land, and therefore its further division according to the structure of use is questionable).

Relying mainly (except for Kosovo) on FAOSTAT land use data [30], the grassland area are considered land under permanent meadows and pastures (which in some cases partly differ from the categories of grassland).

\footnotetext{
* This designation is without prejudice to positions on the status and is in line with UNSCR 1244 and the ICJ Opinion on the Kosovo declaration of independence.
} 
Table 1. Grassland area in WB counters and territories (000 ha) (2018)

\begin{tabular}{|c|c|c|c|c|c|c|c|}
\hline & $\mathrm{AL}$ & $\mathrm{BA}$ & $\mathrm{MN}$ & MK & $\mathrm{RS}$ & XK & Total \\
\hline Agricultural land & $\begin{array}{r}1,17 \\
4\end{array}$ & $\begin{array}{r}2,21 \\
1\end{array}$ & 257 & $\begin{array}{r}1,26 \\
4\end{array}$ & $\begin{array}{r}3,46 \\
4\end{array}$ & 419 & $\begin{array}{r}8,78 \\
9\end{array}$ \\
\hline $\begin{array}{l}\text { Grasslands (permanent meadows and } \\
\text { pastures) }\end{array}$ & 478 & $\begin{array}{r}1,08 \\
2 \\
\end{array}$ & 242 & 805 & 676 & 218 & $\begin{array}{r}3,50 \\
1 \\
\end{array}$ \\
\hline Grasslands in total agricultural land & $\begin{array}{r}40.7 \\
\% \\
\end{array}$ & $\begin{array}{r}48.9 \\
\% \\
\end{array}$ & $\begin{array}{r}94.2 \\
\% \\
\end{array}$ & $\begin{array}{r}63.7 \\
\% \\
\end{array}$ & $\begin{array}{r}19.5 \\
\% \\
\end{array}$ & $\begin{array}{r}52.0 \\
\%\end{array}$ & $\begin{array}{r}39.8 \\
\% \\
\end{array}$ \\
\hline
\end{tabular}

Source: FAOSTAT [25] (except Kosovo*; for Kosovo* - national statistical authority [26]).

In the Western Balkans, $39.8 \%$ of the land belongs to the grassland category. It is most dominant category in Montenegro, with $94.2 \%$ of total agriculture land, and at least dominant in Serbia with only $19.5 \%$ share in total agriculture area. In most of other WB countries, permanent meadows and pastures, i.e. grasslands, make up about half of the total agricultural land. There are no more detailed data on the use of this category of land, as attention is mainly put to arable land which is further divided into cultivated and uncultivated. For grassland areas, determined on the basis of land cover data, it is usually assumed that these areas are also utilized. Grasslands are economically utilized for grazing or preparing fodder (mostly hay) by mowing. Since the end users of these areas are ruminants in both ways, the approach to determine the intensity of grassland use is to put them into ratio with the number of ruminants, as done below.

\subsection{Number of ruminants in the Wester Balkans}

At the end of 2018, there were 2.38 million cattle and 7 million small ruminants (sheep and goats) in the countries and territories of the Western Balkans.

Table 2. Number of ruminants in WB counters and territories (000 heads and LSUs) (2018)

\begin{tabular}{|l|r|r|r|r|r|r|r|}
\hline & \multicolumn{1}{|c|}{ AL } & \multicolumn{1}{c|}{ BA } & \multicolumn{1}{c|}{ MN } & \multicolumn{1}{c|}{ MK } & \multicolumn{1}{l|}{ RS } & \multicolumn{1}{l|}{ XK } & \multicolumn{1}{c|}{ Total } \\
\hline Cattle & 467 & 438 & 87 & 256 & 878 & 259 & 2,385 \\
\hline Sheep & 1,864 & 1,012 & 186 & 727 & 1,712 & 181 & 5,682 \\
\hline Goats & 917 & 73 & 30 & 117 & 196 & 29 & 1,362 \\
\hline LSU & 745 & 547 & 109 & 340 & 1,069 & 280 & 3,089 \\
\hline
\end{tabular}

Source: FAOSTAT [25] (except Kosovo*; for Kosovo* - national statistical authority [26]).

The three types of livestock were converted to livestock standard units (LSU) according to their nutritional needs, using appropriate coefficients [31]. An average coefficient of 1.0 was applied to all cattle, and 0.1 was applied to sheep and goats. This leads to a total of 3 million of ruminants' LSU. Since in the total number of ruminants there are animals of different age, the coefficients applied may be slightly overestimated.

\subsection{Grazing livestock density}

According to the number of LSUs per ha of permanent grasslands, two groups of countries/territories in the WB are distinguished. The first group consists of countries/territories with more than 1 LSU/ha (Serbia, Albania and Kosovo*), and the second group of countries with 0.5 or less LSU/ha (Bosnia and Herzegovina, Montenegro and North Macedonia). The Balkan average is $0.88 \mathrm{LSU} / \mathrm{ha}$. The LSU/ha ratio is usually expressed as a grazing livestock density (GLD) index. In these calculations, equidaes are excluded from grazing animals, although they also graze, but their number is small and cannot significantly change the size of the calculated index. 
Table 3. Grazing livestock density (GLD) index in WB counters and territories (LSU/ha) (2018)

\begin{tabular}{|l|l|l|l|l|l|l|l|}
\hline & AL & BA & MN & MK & RS & XK & Total \\
\hline GLD index & 1.56 & 0.51 & 0.45 & 0.42 & 1.58 & 1.28 & 0.88 \\
\hline
\end{tabular}

Source: Own calculations based on [25] and [26].

Optimization of grassland use by livestock is reached with a balance between the interests of the environmental and the agricultural sector, e.g. crossed between the concerns and benefits of environmentalists and farmers. There are many literature sources on the subject of determining the most favourable ratio of livestock numbers and permanent grassland area, and all of them emphasize that it depends on many factors, such as: production intensity, breed, grass quality, climatic and soil conditions, etc. Often, as a marginal GLD index for a wider geographical area, such as one country, the optimal ratio of LSU/ha of grasslands is 1 (one), that was average value of the livestock intensity in the EU-28 for 2016 (1.0 LSU/ha, ranged from 2.5 LSU/ha in Nederland, to $0.4 \mathrm{LSU} / \mathrm{ha}$ in Latvia) [32]. In the long run, the GLD index in the EU is declining, in 2003 it was 1.11, and in 2007 it was 1.07 [33].

GLD is an indicator of the intensity of grassland use and of the pressure of livestock farming on environment. Two aspects of increasing or decreasing GLD must always be considered - how this will affect the environment and how it will affect farm income and agriculture GDP.

Albania and Serbia have a GLD of around 1.5, and in those countries, there is little room to further increase the number of ruminants, without disturbing the ecological balance. If 1 LSU of ruminants per ha is taken as a marginal for the countries of the Western Balkans that have GLD $<1$, in Bosnia and Herzegovina, Montenegro and North Macedonia there is a space and a need to increase the number of ruminants, in order to exploit unutilized natural potential for development of livestock production, without environmental pressure of grazing animals on grassland area by overgrazing. Using forms of extensive livestock farming, better grassland management would allow increase in meat and milk production, based on grazing and haymaking.

\subsection{Missed economic benefit of unutilized grassland area}

While other professions deal with calculating the benefits of unutilized grasslands on the environment, energy production, biodiversity conservation, etc., this research aims to determine the missed economic benefit from non-utilising these areas for animal breeding and meat production (grasslands are most commonly used for extensive animal husbandry) and points to the opportunity for further development of livestock production based on the optimal use of existing, in some way wasted, natural resources.

Table 4. Deviation in grasslands utilization compared to benchmark $(\mathrm{GLD}=1.0)$

\begin{tabular}{|l|r|r|r|r|r|r|r|}
\hline & \multicolumn{1}{|c|}{ AL } & \multicolumn{1}{c|}{ BA } & \multicolumn{1}{c|}{ MN } & \multicolumn{1}{c|}{ MK } & \multicolumn{1}{c|}{ RS } & \multicolumn{1}{c|}{ XK } & \multicolumn{1}{c|}{ Total } \\
\hline GLD index & 0.56 & -0.49 & -0.55 & -0.58 & 0.58 & 0.28 & -0.12 \\
\hline ha & - & -536 & -133 & -465 & - & - & $-1,134$ \\
\hline LSU & - & -536 & -133 & -465 & - & - & $-1,134$ \\
\hline
\end{tabular}

Source: Own calculations.

The initial calculation showed that in the WB region there are 1.1 million ha of unutilized grasslands, with a conservative assumption of utilization of 1 ha of grassland with 1 LSU. At the same time, this means that there are conditions for increasing the number of ruminants by 1.1 million LSU. As explained in the methodology, the first scenario (S1) is based on the increase in the number of ruminants following their current 
structure, and the second (S2) is based on change that structure in favour of a greater representation of sheep and goats.

Table 5. Projection of increase in the number of ruminants

\begin{tabular}{|c|c|c|c|c|c|c|c|c|c|c|}
\hline & & \multicolumn{3}{|c|}{$\mathrm{BA}$} & \multicolumn{3}{|c|}{$\mathrm{MN}$} & \multicolumn{3}{|c|}{ MK } \\
\hline & & Share & $\begin{array}{c}000 \\
\text { LSU }\end{array}$ & $\begin{array}{c}000 \\
\text { heads }\end{array}$ & Share & $\begin{array}{c}000 \\
\text { LSU }\end{array}$ & $\begin{array}{c}000 \\
\text { heads }\end{array}$ & Share & $\begin{array}{c}000 \\
\text { LSU }\end{array}$ & $\begin{array}{c}000 \\
\text { heads }\end{array}$ \\
\hline \multirow{3}{*}{ S1 } & Cattle & 0.80 & 429 & 429 & 0.80 & 107 & 107 & 0.75 & 349 & 349 \\
\hline & Sheep & 0.19 & 99 & 992 & 0.17 & 23 & 230 & 0.21 & 99 & 992 \\
\hline & Goats & 0.01 & 7 & 72 & 0.03 & 4 & 37 & 0.03 & 16 & 160 \\
\hline \multirow{3}{*}{$\mathrm{S} 2$} & Cattle & 0.55 & 295 & 295 & 0.55 & 73 & 73 & 0.55 & 256 & 256 \\
\hline & Sheep & 0.40 & 214 & 2,142 & 0.40 & 53 & 534 & 0.40 & 186 & 1,858 \\
\hline & Goats & 0.05 & 27 & 268 & 0.05 & 7 & 67 & 0.05 & 23 & 232 \\
\hline
\end{tabular}

Source: Own calculations.

In the case of full utilization of currently unutilized grasslands in three WB countries, the extensive livestock system could feed about 885 thousand cattle, 2.2 million sheep and 270 thousand goats, or about 620 thousand cattle, 4.5 million sheep and 570 thousand goats in the case of changed livestock structure. This data sounds too optimistic, but also realistic, because Bosnia and Herzegovina, Montenegro and Macedonia had approximately the same number of cattle and sheep in 1950 [34] and goats immediately after the end of the Second World War (later it was forbidden to keep goats in the SFRY) [35].

The last phase in the analysis is to determine the value of the increase in the number of livestock, for each of the two scenarios. Considering that there may be different breeding systems in terms of weight gain and duration of breeding, the following average parameters were taken to calculate the value of production: output live weight of fattened cattle $300 \mathrm{~kg}$ and lambs and kids $25 \mathrm{~kg}$; the selling prices of live cattle, lambs and kids $2.0 \mathrm{EUR} / \mathrm{kg}$ (approximate prices based on the trends of livestock prices in Serbia, which is the only one in the WB region to have an agricultural market information system, in October 2020).

Table 6. Market value of increased number of ruminants (000 EUR)

\begin{tabular}{|c|c|c|c|c|}
\hline Scenario & BA & MN & MK & Total \\
\hline S1 & 310,664 & 77,370 & 267,242 & 655,276 \\
\hline S2 & 229,895 & 57,373 & 210,907 & 498,176 \\
\hline
\end{tabular}

Source: Own calculations.

\section{Discussions}

Grasslands are a valuable resource that can be multiple used, whether to feed ruminants by grazing or preparing grass fodder for delayed use. Depending on the intensity of livestock production, up to $2.5 \mathrm{LSU}$ can be fed from 1 ha of grasslands. The grasslands in the Western Balkans are extensively manged, with low inputs, and low output effects. In some WB countries, GLD is within the limits of semi-intensive use and according to the principles of HNV land management. In other WB countries, grasslands are very poorly utilized, which disrupts plant diversity, leading to the disappearance of many typical grassland species [36].

The question is why grasslands are poorly utilized in some Western Balkans countries (primarily Bosnia and Herzegovina, Montenegro and Northern Macedonia)? Some of the reasons are as follows:

- Rural areas are affected by long-term migration and simply there is no labour for cattle breeding, which is labour intensive; 
- Livestock production is intensifying and enlarging, from pasture raised to indoor farming, which significantly reduces grazing, and increases the use of concentrated nutrients;

- Extensive sheep breeding was mainly based on a nomadic system, less and less practiced (due to legal prohibition and the changed shepherds' lifestyle);

- Dominance of small and fragmented holdings and small farms that are less competitive compared to large livestock farms;

- Broken supply chains that complicate sales of live animals (slaughterhouses and the meat processing industry are turning to meat imports);

- Suppression of domestic milk and meat production on local market due to import of cheaper products as a consequence of the liberalization of the foreign trade regime;

- Insufficient market positioning of food produced on organic and HNV principles;

- Absence of ANC delimitation and agri-environmental incentive schemes;

- Lack of incentives that favour extensive animal husbandry.

Despite these limitations, there is room for better use of grasslands in the Western Balkans through an increase in ruminant number, based on new farming models and the introduction of technological innovations. In addition to new and proper breeding programs, in accordance with new technological trends, there is room for the introduction of scientific and technological innovations in ruminant breeding.

Finally, by optimizing the number of ruminants with free-range grasslands, in the three WB countries that have a livestock deficit compared to grassland areas, value of livestock production could increase up to EUR 498 million (S2) or 655 million (S1), which would also represent gross output for livestock farmers. If the final number of ruminants is taken as a medium-term goal, any increase in their number in the short-term leads to an increase in the value of livestock production and farmer income, which does not require large investments, since it is based on an extensive livestock system.

Increasing food production through better and greater use of grasslands contributes to the achievement of Sustainable Development Goals - Zero Hunger (SDG 2). A moderate livestock intensity ensures also ecological sustainability of the use of grasslands and maintaining a high level of biodiversity, positive grasslands' environmental footprint and contribute in establishing areas of high natural value.

\section{Conclusions}

Applying extensive livestock production thanks to pastoral systems of grassland utilization has positive environmental impact. However, this livestock system also has positive economic effects, as the costs of feeding ruminants based on grazing and haymaking are low and low capital intensive, which is particularly suitable for less developed countries and small farms. Nevertheless, extensive livestock farming based on grassland utilization is more present in developed than in developing countries, as is the case in the Western Balkans. Grazing-based livestock farming is not popular within the younger generation, and it is not particularly profitable due to the unregulated market and unfavourable subsidies. Due to all this, three Balkan countries potentially lose around EUR 500 million a year, and succession of grassland vegetation has negative environmental consequences.

Traditional values of grasslands can be preserved and make attractive again with the application of new IC and other modern technology solutions, such as: digital land cover and lend use classification and monitoring, electronic animal tracking, grasslands management by application of precision agriculture techniques (remote sensing, drones, satellite monitoring, etc.), quantitative optimization of grazing management systems, labour-savings technologies (specialized agricultural machinery, virtual fencing, etc.), biogas production from grass, machine learning forecasting model of grass yield estimation, decision support tools based on artificial intelligence, automated animal health 
management, branding high quality products of grassland-based systems, digital promotion and marketing of HNV products, etc.

\section{References}

1. Nábrádi, A. (2007). The economic value of grassland products. Applied Studies in Agribusiness and Commerce, 1(1), 19-28.

2. O'Mara, F.P. (2012) The role of grasslands in food security and climate change. Annals of Botany, 110(6), 1263-70.

3. Peeters, A. (2008). Challenges for grasslands, grassland-based systems and their production potential in Europe. Grassland science in Europe, 13(August), 9-24.

4. Plantureux, S., Peeters, A., Mc Cracken, D. (2005). Biodiversity in intensive grasslands : Effect of management, improvement and challenges. Agronomy research, 3(2), 153-164;

5. Gibon, A. (2005). Managing grassland for production, the environment and the landscape. Challenges at the farm and the landscape level. Livestock Production Science, 96(1), 11-31.

6. Arsić, S., Jovanović, M., Sredojević, Z. (2015). Comparative analysis of the number of sheep in FYR and some European countries. Economics of Agriculture, 62(2), 453466.

7. Farinella, D., Nori, M., Ragkos, A. (2017). Changes in Euro-Mediterranean pastoralism: which opportunities for rural development and generational renewal? Proceedings of the 19th Symposium of the European Grassland Federation, Alghero, Italy, 7-10 May 2017, 23-36.

8. Besnard, A.G., Secondi, J. (2014). Hedgerows diminish the value of meadows for grassland birds: Potential conflicts for agri-environment schemes. Agriculture, Ecosystems and Environment, 189(May), 21-27.

9. Britschgi, A., Spaar, R., Arlettaz, R. (2006). Impact of grassland farming intensification on the breeding ecology of an indicator insectivorous passerine, the Whinchat Saxicola rubetra: Lessons for overall Alpine meadowland management. Biological Conservation, 130(2),193-205.

10. Teague, W.R., Apfelbaum, S., Lal, R., Kreuter, U.P., Rowntree, J., Davies, C.A, Conser, R., Rasmussen, A.M., Hatfield, J., Wang, T. (2016). The role of ruminants in reducing agriculture's carbon footprint in North America. Journal of Soil and Water Conservation, 71(2), 156-64.

11. Zheng, X., Zhang, J., Cao, S. (2018). Net value of grassland ecosystem services in mainland China. Land Use Policy, 79 (Decembar 2018), 94-101.

12. Chapman, D.F., Parsons, A.J., Cosgrove, G.P., Barker, D.J., Marotti, D.M., Venning, K.J., Rutter, S.M., Hill, J., Thompson, A.N. (2007). Impacts of spatial patterns in pasture on animal grazing behavior, intake, and performance. Crop Science, 47, 399416.

13. Tälle, M., Deák, B., Poschlod, P., Valkó, O., Westerberg, L., Milberg, P. (2016). Grazing vs. mowing: A meta-analysis of biodiversity benefits for grassland management. Agriculture, Ecosystems and Environment, 222, 200-212.

14. Laterra, P., Agrarias, C. (2011). From multifunctional grasslands to multifunctional landscapes. IX International Rangeland Congress, Volume: Proceedings I, Rosario, Argentina, 2011, 709-713.

15. Wehn, S., Hovstad, K.A., Johansen, L. (2017). The effect of landscape structure on biodiversity in semi-natural grasslands of high nature value. Proceedings of the 19th Symposium of the European Grassland Federation Alghero, Italy 7-10 May 2017, 277-279.

16. Li, M., Wu, J.J., Deng, X. (2013). Identifying drivers of land use change in China: A 
spatial multinomial logit model analysis. Land Economics, 89(4), 632-654.

17. Eriksson, O., Cousins, S.A.O., Bruun, H.H. (2002). Land-use history and fragmentation of traditionally managed grasslands in Scandinavia. Journal of Vegetation Science, 3(5), 743-748.

18. Le, C., Ikazaki, K., Siriguleng, S., Kadono, A., Kosaki, T. (2013). Grassland degradation caused by tourism activities in Hulunbuir, Inner Mongolia, China. 8th International Symposium of the Digital Earth (ISDE8), 26-29 August 2013, Kuching, Sarawak, Malaysia, OP Conf. Series: Earth and Environmental Science18(2014) 012137.

19. Barkmann, J., Zschiegner, A.K. (2010). Grasslands as a sustainable tourism resource in Germany: Environmental knowledge effects on resource conservation preferences. International Journal of Services, Technology and Management, 13(3-4), 174-191.

20. Van den Pol-van Dasselaar, A., Hennessy, D., Isselstein, J. (2020). Grazing of dairy cows in europe-an in-depth analysis based on the perception of grassland experts. Sustainability, 2(3), 1098.

21. Jacquot, A.L., Brunschwig, G., Delaby, L., Pomies, D., Lamadon, A., Baumont, R. (2017). Dynamilk: a model at farm-scale to explore the balance between forage and milk production. Proceedings of the 19th Symposium of the European Grassland Federation Alghero, Italy 7-10 May 2017, 85-87.

22. Lessire, F., Scohier, C., Dufrasne, I. (2017). Impact of grazing practices on farm selfsufficiency, milk and economic performances of three automatized farms. Proceedings of the 19th Symposium of the European Grassland Federation Alghero, Italy 7-10 May 2017, 182-184.

23. Osoro, K., Ferreira, L.M.M., García, U., Martínez, A., Celaya, R. (2017). Performance of two herd types: suckler cows vs sheep-plus-goats grazing on partially improved heathlands. Proceedings of the 19th Symposium of the European Grassland Federation Alghero, Italy 7-10 May 2017, 206-208.

24. Goliński, P., Golińska, B., Paszkowski, A. (2017). Effectiveness of heifers grazing on extensive grassland situated in the B. Papi Reserve. Proceedings of the 19th Symposium of the European Grassland Federation Alghero, Italy 7-10 May 2017, 323-325.

25. FAOSTAT (2020). Data. 2020. Available from: http://www.fao.org/faostat/en/\#data

26. Kosovo Agency of Statistics (2019). Farm Structure Survey 2018. Available from: https://ask.rks-gov.net/media/5393/anketa-poljoprivrednih-domačinstva-2018.pdf

27. Sanderson, M., Wedin, A.D., Tracy, B. (2005). Grassland: Definition, Origins, Extent, and Future. In: Plant Production and Protection, Series No 34. FAO, Rome.

28. Velthof, G.L., Lesschen, J.P., Schils, R.L.M., Smit, A., Elbersen, B.S., Hazeu, G.W., Mucher, C.A., Oenema, O. (2014). Grassland areas, production and use. Alterra Wageningen UR, Wageningen (40701).

29. Lesschen, J.P., Elbersen, B., Hazeu, G., Van Doorn, A., Mucher, S., Velthof, G. (2016). Task 1 - Defining and classifying grasslands in Europe. Alterra Wageningen UR, Wageningen.

30. FAOSTAT (2020). Land use. Available from: http://www.fao.org/faostat/en/\#data/RL

31. EUROSTAT (2020). Livestock unit coefficients. Available from: https://ec.europa.eu/eurostat/statisticsexplained/index.php/Glossary:Livestock_unit_(LSU)

32. EUROSTAT (2019). Agri-environmental indicator - livestock patterns. Statistics Explained. Available from: http://ec.europa.eu/eurostat/statisticsexplained/index.php/Agri-environmental_indicator_-_livestock_patterns

33. European Union (2011). Agriculture and fishery statistics. Main results 2019-10. 
Luxembourg: Publications Office of the European Union.

34. Miljković, D., Nikolić, M. (1996). Razvoj republika prethodne SFR Jugoslavije 19471990 godina /Development of the republics of the former SFR Yugoslavia 1947-1990/. Belgrade, Federal Birou of Statistics.

35. Ziani, P. (1964). Problemi uzgoja koza u Jugoslaviji /Problems of goat breeding in Yugoslavia/. Šumarski glasnik, 88(7-8), 277-306.

36. Peeters, A., Resources, N., Environment, H., Grasses, P. (2015). Environmental impacts and future challenges of grasslands and grassland- based livestock production systems in Europe Grassland. In book: Grasslands, A Global Resource Perspective, Edition: International Grassland Congress and Range Management Society of India, Chapter: 17, Lucknow (India), Army Printing Press. 